\title{
EXPERIMENTAÇÃO DIDÁTICA COM O AUXÍLIO DA PEDAGOGIA DE PROJETOS: O TEATRO COMO RECURSO LÚDICO VISANDO À INTEGRAÇÃO DA EDUCAÇÃO FINANCEIRA NAS AULAS DE MATEMÁTICA
}

\author{
DIDACTIC EXPERIMENTATION WITH THE AID OF PROJECT PEDAGOGY: THEATER AS A \\ PLAYFUL RESOURCE AIMED AT INTEGRATION FINANCIAL EDUCATION
}

(i) https://orcid.org/0000-0002-0628-1195 Nelson Machado Barbosa (b) https://orcid.org/0000-0002-9517-2088 Jonatas Campos Sarlo https://orcid.org/0000-0001-9193-6012 Eduardo Corrêa dos Santos

\footnotetext{
${ }^{\text {A }}$ Universidade Estadual do Norte Fluminense Darcy Ribeiro (UENF), Campos dos Goytacazes, RJ, Brasil

${ }^{\text {B }}$ Universidade Estadual do Norte Fluminense Darcy Ribeiro (UENF), Campos dos Goytacazes, RJ, Brasil ${ }^{\mathrm{C}}$ Colégio Estadual Pedro Cerqueira (CEPC), São Francisco de Itabapoana, RJ, Brasil.
}

\section{Resumo}

Este artigo apresenta uma experimentação didática baseada na pedagogia de projetos com uma prática pedagógica diferenciada, o Teatro, visando o desenvolvimento do senso de autonomia do aluno nas aulas de matemática, concentrando-se em envolver ativamente os estudantes no desenvolvimento do entendimento da Educação Financeira contextualizada, trabalhando de forma independente e cooperativa na tomada de decisão em situações-problema. A partir dos resultados, pode-se perceber que os estudantes puderam desenvolver os processos cognitivos ensinados, sendo capazes de transferi-los para novas situações em economia doméstica e matemática financeira através da ambientação cênica elaborada, totalmente centrada nos conceitos da interdisciplinaridade e transversalidade.

Palavras-chave: Pedagogia de projetos; Arte educação; Teatro; Educação financeira.

\begin{abstract}
This article presents a didactic sequence based on the project pedagogy with different pedagogical practices, the theater, aimed at developing the student's sense of autonomy, focusing on actively involving students in developing an understanding of contextualized Financial Education, working independently and cooperatively in decision making in problem situations. From the results, it can be seen that students were able to develop the cognitive processes taught, being able to transfer them to new situations in financial mathematics and domestic economic through the elaborate scenic setting, totally centered on the concepts of interdisciplinarity and transversality.
\end{abstract}

Keywords: Project pedagogy; Art education; Theater; Financial education. 


\section{Introdução}

A sociedade brasileira, com sua vertente capitalista, não possui uma cultura para aprender Educação Financeira. Os brasileiros, ainda de forma não proposital, adquirem o hábito de financiar, parcelar compras, não poupar ou investir. Dados dos Relatórios Econômicos da Organização para a Cooperação e Desenvolvimento Econômico (OCDE) revelam que a maioria dos trabalhadores brasileiros não seria capaz de manter o padrão de vida, caso ficassem sem receber o seu salário por menos de dois meses. Essa informação demonstra um perfil imediatista na forma de gastar, não priorizando o ato de poupar e investir. A homologação da Base Nacional Comum Curricular (BNCC), em meio a esse cenário, trouxe acréscimos no currículo de matemática, pois obriga, em forma de lei, a inclusão desse conteúdo nas escolas, a partir do ano de 2020 .

Com a homologação da BNCC (BRASIL, 2018), a Educação Financeira chega às salas de aula, no Brasil, de forma obrigatória e não mais como mera sugestão de abordagem dentro da Matemática Financeira. O desenvolvimento de competências para o conhecimento e habilidades em matemática tendo como pano de fundo a Educação Financeira, desde o ensino fundamental, foi ênfase na última atualização desse documento.

A BNCC deixa clara a necessidade do aprendizado que apresente simulações de projetos de pesquisa que visem a ensinar ao aluno o processo investigativo e a coleta das informações relevantes, organizando e tratando os dados para que outro leitor consiga entender. Conforme D’Ambrosio (1986) o experimento da pesquisa transforma o aluno em um cidadão crítico, fazendo com que ele consiga entender assuntos variados, tornando-o capaz de tomar decisões de forma mais segura.

A inclusão da Educação Financeira segue tendências de estudos recentes, segundo a Associação Brasileira dos Educadores Financeiros (ABEFIN). De acordo com a Estratégia Nacional de Educação Financeira (ENEF) - (ENEF, 2019), que foi criada com o Decreto Federal 7.397/2010 (BRASIL, 2010), com os resultados da Pesquisa Nacional de Educação Financeira nas Escolas, mais de $80 \%$ dos alunos que tiveram contato com a Educação Financeira conseguem guardar parte do que recebem para planos futuros.

No documento da BNCC sugere-se que o trabalho com a Educação Financeira seja de maneira transversal e integrada, de modo que cada escola adote uma maneira de articular o tema em seus currículos. Vale ressaltar que o referido conteúdo está além de compreender juros, descontos e porcentagens e deve ser abordado de forma que provoque uma reflexão consciente sobre a postura frente ao dinheiro. Deve ser trabalhado pelo professor de forma interdisciplinar 
e transversal. É preciso que seja informado aos alunos que guardar ou economizar dinheiro vai além de usar cofrinhos para tais práticas. É fundamental que seja gerada uma visão de que o planejamento financeiro sustentável é importante para o futuro.

A preparação para esse mundo requer que se aprenda a abordar problemas reais com atitude e confiança. Os estudantes precisam desenvolver a vontade de lidar com problemas, embasados no conhecimento que já possuem ou que irão adquirir por conta própria, sem fazer uso de um método de solução pré-aprendido (PATARO; SOUZA, 2012). Para uma educação financeira eficaz é preciso desenvolver neles hábitos mentais que os encorajem a resolver problemas maiores, subdividindo-os em menores e que possam criar uma relação dos novos com aqueles que já foram resolvidos, levando-os a tomar decisões tanto de maneira estratégica quanto flexível.

Portanto, a partir da homologação da BNCC, a Educação Financeira torna-se um componente obrigatório no currículo de Matemática no Ensino Básico. Com isso, faz-se oportuna a aplicação de conceitos da matemática financeira dentro do assunto de Educação Financeira, passando a percorrer, agora, o caminho inverso ao que era de costume, tratando a Educação Financeira como o assunto primário e a matemática financeira como uma ferramenta.

A BNCC para o Ensino Médio define que o aprendizado essencial deve ser garantido para os estudantes, ela ainda instrui sobre a criação ou adequação de propostas e currículos pedagógicos. Suas competências são dez, a saber: conhecimento (processo de construção do saber); pensamento científico crítico e criativo (desenvolvimento do raciocínio); contexto cultural (produção de conteúdo artístico desenvolvido pelos estudantes); comunicação (sair do convencional nas relações interpessoais); cultura digital (uso de tecnologias para a educação); trabalho e projeto de vida (planejar e gerenciar objetivos); argumentação (promover discussão com dados e informações bem fundamentadas); autoconhecimento e autocuidado (equilíbrio entre a saúde emocional e física); empatia e cooperação (desenvolver os relacionamentos sociais) e responsabilidade e cidadania (promover no estudante a capacidade de construir, de forma participativa, uma sociedade justa e solidária).

Com o intuito de atender, de forma amplificada as competências da BNCC para um aprendizado essencial, pensou-se em atividades como Teatro, com exercícios envolvendo temas para que o aluno consiga relacionar com seu cotidiano com auxílio de problematizações contextualizadas, como norteadores das tarefas da metodologia desta pesquisa, uma vez que em um projeto todos são instigados a se envolver ativamente nas atividades. 
Assim, o objetivo principal desta pesquisa é apresentar uma experimentação didática visando o Teatro como prática pedagógica facilitadora no desenvolvimento do senso de autonomia do estudante, com tomadas de decisão que estejam concentradas, ativamente, no envolvimento dele e no desenvolvimento do entendimento dos conceitos da Educação Financeira, conduzindo-o a investigações e registrando descobertas. Ressalta-se a necessidade de uma aprendizagem baseada em projetos, cuja pedagogia é centrada no discente, com a inserção de uma abordagem dinâmica, em sala de aula, que vise à aquisição de um conhecimento mais profundo, através da exploração ativa de desafios e problemas do mundo real. Como objetivos específicos, espera-se demonstrar que o Teatro pode ser utilizado como recurso pedagógico para ensino-aprendizagem do tema proposto, enfatizando a importância da Educação Financeira no cotidiano dos estudantes, ensinando de forma diferenciada, conceitos como: taxa de juros, inflação, impostos, investimentos; contribuindo para a sua formação em Educação Financeira.

Por fim, vale ressaltar que este artigo é um recorte do resultado da pesquisa de mestrado realizada pelo Programa de Pós-graduação Profissional em Matemática em Rede Nacional (PROFMAT) defendida em 2019.

\section{As concepções da educação financeira no brasil}

Muitas atividades cotidianas do indivíduo, enquanto ser social, estão correlacionadas ao uso e aplicação do dinheiro. Tão importante quanto manusear o dinheiro em nosso dia a dia, é saber geri-lo da melhor forma ou tomar a melhor decisão ao aplicá-lo. Lamentavelmente, a falta de preparo e insuficiência de maturidade financeira são agravantes que contribuem para elevar o endividamento do cidadão ou induzir ao consumismo exagerado, sem considerar as consequências dos fatos. Refletir e discutir ações que contribuam para ampliar a compreensão de concepções financeiras inseridas em nossas vidas, nos espaços escolares, são algumas das iniciativas propostas pela Educação Financeira. Saito (2007) define a educação financeira da seguinte forma:

A Educação Financeira pode ser entendida como um processo de conhecimento que permite o aprimoramento da capacidade financeira dos indivíduos, de modo que estes possam tomar decisões fundamentadas e seguras, tornando-as mais integrados à sociedade com uma postura pró ativa na busca de seu bem-estar. (SAITO, 2007, p. 20-21)

O debate acerca da Educação Financeira partiu de investigações desenvolvidas pela Organização para a Cooperação e Desenvolvimento Econômico (OCDE), órgão que tem por propósito fomentar e potencializar as políticas públicas voltadas ao desenvolvimento 
econômico permanente e, promover o bem-estar social da população mundial, entre os países membros e não membros.

No Brasil, seguindo a propensão mundial, o início das ações governamentais se deu a partir de 2007, por meio da formação do Comitê Nacional de Educação Financeira (CONEF). Num trabalho conjunto, representantes do governo, da iniciativa privada e da sociedade civil se uniram para desenvolver a Estratégia Nacional de Educação Financeira (ENEF), sendo esta, uma mobilização multisetorial em torno da promoção de ações de Educação Financeira no Brasil.

Na concepção de Souza (2012), "a aprovação da ENEF, foi um ponto onde se constata que, [...], o Brasil está dando a devida importância para a educação financeira."

No período de 2010 a 2011, a ENEF iniciou um projeto da Educação Financeira nas escolas aplicando um projeto piloto em 891 escolas públicas de Ensino Médio, em seis unidades da federação. Para o projeto piloto, foi criado pela ENEF um documento de Orientações para Educação Financeira nas Escolas, que teve por objetivo a inserção da Educação Financeira nas escolas apresentadas em dois grupos: o Espacial e o Temporal.

Na Dimensão espacial o objetivo era formar para a cidadania, como também ensinar a consumir e a poupar ou investir de modo ético, consciente e responsável, oferecendo conceitos e ferramentas para a tomada de decisão autônoma baseada em mudança de atitude, sem esquecer de perpetuar o projeto, formando disseminadores.

Na Dimensão temporal o objetivo era ensinar a planejar a curto, médio e longo prazos, desenvolvendo a cultura da prevenção e proporcionar possibilidade de mudança da condição atual. Desta forma, ao abordar no âmbito individual, o projeto sugere temas como o equilíbrio da vida financeira, consumo e poupança e no âmbito social sugere temas com variáveis da vida financeira e instituições que compõem o Sistema Financeiro Nacional.

Por conseguinte, temos a publicação elaborada pelo ENEF chamada de Resultados da Avaliação de Impacto do Projeto Piloto de Educação Financeira nas Escolas:

\footnotetext{
Nossos resultados sugerem que o programa de educação financeira nas escolas aumentou o conhecimento financeiro dos alunos e melhorou suas atitudes financeiras. O programa também levou a mudanças no comportamento financeiro dos alunos. Especificamente, devido ao programa, os alunos estão mais propensos a poupar e administrar suas despesas, conversar com seus pais sobre questões financeiras e ajudar a organizar o orçamento familiar. Esses efeitos se mantiveram no curto e no longo prazo, o que permite afirmar a sustentabilidade e longevidade do treinamento que os alunos receberam (ENEF, 2010, p.2).
}

Em 2014, a ENEF lançou uma plataforma aberta de acesso aos livros de educação financeira, disponibilizando todo o conteúdo para download de forma gratuita, possibilitando a 
todos uma continuação do projeto. Vale resaltar que este material foi utilizado na criação da experimentação didática proposta neste artigo.

O Programa de Educação Financeira nas Escolas contempla dois projetos, estes estão voltados para o Ensino Fundamental e Ensino Médio, apresentados por um projeto pedagógico e um conjunto de livros para professor e aluno, em cada nível de ensino.

O programa foi testado, como projeto piloto, entre maio de 2010 e dezembro de 2011, em turmas do $2^{\circ}$ e $3^{\circ}$ anos do Ensino Médio. Foram envolvidas 891 escolas públicas no Distrito Federal e nos estados do Tocantins, Rio de Janeiro, Minas Gerais, São Paulo e Ceará, tendo a participação de 1.200 educadores e cerca de 27.000 alunos, com idades entre 14 a 17 anos, obtendo resultados satisfatórios (BRASIL, 2012).

A experiência de se informar sobre finanças produziu transformações significativas na vida dos jovens estudantes e de suas famílias, e rendeu ao Brasil referência nessa modalidade de ensino. O relatório The impact of high school financial education - experimental evidence from Brazil, do Banco Mundial, apontou os benefícios do projeto para a população jovem brasileira. A avaliação do Banco Mundial apontou que os jovens estudantes aumentaram a capacidade de economizar, listar despesas mensais, negociar preços e formas de pagamentos, projetar planos futuros, além de discutir sobre orçamento doméstico com a família (BRUHN et al., 2013). Por conseguinte,

A implantação da Educação Financeira nas escolas se justifica por diversas razões amplamente estudadas pelos países que já acumularam experiência na área. Dentre essas razões se destacam os benefícios de se conhecer o universo financeiro e de tomar decisões financeiras adequadas, que fortaleçam o comando autônomo da própria vida e, por extensão, do âmbito familiar e comunitário (BRASIL, 2010, p. 1).

Entretanto, a Educação Financeira, no Brasil, ainda é um assunto pouco recorrente para boa parte da população, tanto no ambiente familiar, quanto nos espaços escolares. Sobre o descaso e a pouca importância dada ao assunto nas instituições públicas de ensino, Martins (2011) faz duras críticas às políticas educacionais do país.

\footnotetext{
Os formuladores das políticas de ensino nunca explicaram porque dão mais importância a nomes de reis e rainhas do que a noções de comércio, de finanças e de impostos. Esse problema não é exclusivamente brasileiro. Mesmo na Europa e nos Estados Unidos, a educação financeira não faz parte das políticas educacionais, ou pelo menos não fazia, pois, aos poucos, esse assunto vem sendo introduzido nos currículos escolares (MARTINS, 2011, p. 56).
}

Do mesmo modo, tratar de planejamento de finanças, consumo consciente, orçamento doméstico, dentre outras questões pertinentes ao tema dinheiro, também não é usual.

A Educação Financeira nos países desenvolvidos tradicionalmente cabe às famílias. Às escolas fica reservada a função de reforçar a formação que o aluno adquire em 
casa. No Brasil, infelizmente, a Educação Financeira não é parte do universo educacional familiar. Tampouco escolar. Assim, a criança não aprende a lidar com dinheiro nem em casa, nem na escola. As consequências deste fato são determinantes para uma vida de oscilações econômicas, com graves repercussões tanto na vida do cidadão, quanto na do país (D’AQUINO, 2010, p.1).

Sobre o pensamento de D’Aquino (2010), a necessidade de inserção do tema Educação Financeira nas escolas públicas brasileiras é recorrente de discussões acerca da premência de estimular o desenvolvimento de habilidades que propiciem a reflexão do comportamento dos indivíduos frente à autonomia financeira consciente.

Destarte, no que diz respeito à abordagem da Educação Financeira nas instituições escolares, o tema é mencionado nas diretrizes e orientações educacionais dos PCN para o Ensino Fundamental II "podendo ser estendido ao Ensino Médio". Os PCN que tratam dos Temas Transversais, apresentam o capítulo Trabalho e Consumo e sugere a necessidade de abordar questões relacionadas à Educação Financeira no ambiente escolar, embora ainda não haja a clara exigência, por parte do sistema educacional brasileiro.

Não há obrigatoriedade da educação financeira no sistema de ensino. O MEC preconiza a contextualização do ensino, que pressupõe um processo de aprendizagem apoiado no desenvolvimento de competências para inserção dos estudantes na vida adulta, mediante a multidisciplinaridade, o incentivo do raciocínio e da capacidade de aprender (SAVOIA et al., 2007, p. 1134).

A despeito da relação que se faz, a Educação Financeira se volta à prática de conceitos não apenas matemáticos, além disso, direciona a aquisição de uma postura consciente ao consumo responsável, sustentável e favorável.

Os autores Silva e Powell (2013) consideram que seja importante a inserção da Educação Financeira nas escolas públicas brasileiras, até por ser um tema em voga em vários países. Em observância aos documentos e material didático produzidos para o Programa de Educação Financeira nas Escolas, os autores analisam com apreensão, que aspectos como a carência de cursos de formação voltados para a capacitação de profissionais da educação e a participação apenas de representantes do governo e de profissionais ligados a entidades financeiras particulares na elaboração da proposta do programa de Educação Financeira nas Escolas, caracterizando-os como pontos negativos, que podem contribuir para o insucesso do mesmo. No entanto, ponderam que no Brasil, presentemente, há um crescente número de pesquisadores do campo da Educação Matemática interessados em ampliar a discussão, investigação e reflexão a respeito da Educação Financeira e sua implantação nas escolas públicas, sendo tal fator o diferencial para o avanço do programa nas instituições públicas. 
A ampliação da temática Educação Financeira em sala de aula será um dos focos deste artigo, onde se propõem uma experimentação didática através do Teatro juntamente com problematizações contextualizadas, que envolvem o assunto de forma clara, concisa e conscientizadora, conectando os estudantes aos conceitos da matemática financeira e economia doméstica, inspirado no Projeto Educação Financeira nas Escolas.

\section{Pedagogia de projetos: o teatro como recurso didático}

O cenário envolto às mudanças tecnológicas impõe a necessidade de profissionais com um novo perfil, que sejam capazes de enfrentar os desafios crescentes para garantir a competitividade das organizações no mercado. Faz-se necessário um novo olhar para as metodologias de ensino, que desenvolva habilidades para um bom desempenho acadêmico e profissional dos estudantes.

A Pedagogia de Projetos pode ser conceituada como uma metodologia de ensino de desenvolvimento que ocorre através da experiência, onde o discente estará conectado com atividades concretas (NOGUEIRA, 2003). O educador é o préstimo, facilitador, mediador e direcionador, propondo caminhos baseados nas descobertas espontâneas dos alunos. A Pedagogia de Projetos muda o formato das aulas tradicionais, nas quais se trabalha com a transferência do conhecimento e a memorização, para um espaço livre e real de múltiplas interações (PERUCHI, 2018). Sob essa ótica, não há mais a formação somente da parte intelectual. Estão envolvidos neste processo os aspectos cognitivos, emocionais e sociais. Tratase de um processo mais complexo, o qual se aprende vivenciando situações, analisando fatos e dados, compartilhando opiniões e definindo as melhores ações para atingir os objetivos esperados.

A Pedagogia de Projetos tem como objetivo desenvolver, no discente, habilidades e competências como: autonomia, criatividade, capacidade analítica, de síntese e o poder de decisão. Ela deve oportunizar aos alunos a contextualização de conceitos e eles, sozinhos, descobrem outras possibilidades, durante o desenvolvimento do trabalho, trazendo novas experiências e conhecimentos para sua vida.

Para Martins (2007), o projeto como instrumento de aprendizagem e compreensão da realidade deve estimular os alunos a buscar soluções para as questões e problemas propostos, levando em consideração seus conhecimentos prévios e possibilitando o aprimoramento e o desenvolvimento de suas competências. 
A implementação da pedagogia de projetos nas escolas visa trazer aos alunos um jeito novo e mais amplo de aprender. Precisa-se entender essa nova visão que remete à necessidade de aprender a conhecer; a fazer; a viver e a ser. Isso nos dá a compreensão das ramificações do conhecimento e nos permite entender o mundo que nos cercam. Cria-se as habilidades para aplicar a teoria na prática. Possibilita o melhor conhecimento dos outros, através do compartilhamento de ideias durante os trabalhos em equipe. Orienta-se o estudante, preparando-o para ter pensamentos autônomos e críticos.

Em reflexão dessa linha de pensamento, este artigo utiliza o Teatro como um recurso didático para o ensino, aprendizado e conscientização da Educação Financeira, inserido numa abordagem da pedagogia de projetos.

Vale ressaltar que o Teatro, como recurso pedagógico na Educação brasileira somente tomou corpo a partir do crescimento da atividade industrial, no início do século XX. A partir desta data, o ensino das artes passa a fazer parte da educação primária e secundária e as práticas pedagógicas, em curso, foram substituídas por ações educativas que valorizavam a criação, o desenvolvimento e davam espaço para a espontaneidade e o progresso do estudante.

Para Figueiredo (2008), uma criança pode vir a aprender sem utilizar o lúdico, mas este proporcionará um aprendizado mais rápido, alegre e sólido. O Teatro é ainda um recurso novo como forma de ensino-aprendizado para muitos profissionais da educação, porém vem sendo discutido e aceito em inúmeras instituições de ensino. Alves (2010) corrobora com essa afirmação e ainda reitera a importância do Teatro para a interação, desenvolvimento cognitivo, psico-motor e social dos estudantes.

Para Gonzaga (2018), o Teatro promove habilidades de comunicação; trabalho em equipe; diálogo; negociação e socialização. Estimula a imaginação e criatividade, desenvolvendo no aluno uma melhor compreensão do comportamento humano e empatia com situações que podem parecer distantes.

Na BNCC o Teatro como um recurso, constrói a prática da arte multissensorial, criação coletiva, colaborativa e ainda: "O fazer teatral possibilita a intensa troca de experiências entre os alunos e aprimora a percepção estética, a imaginação, a consciência corporal, a intuição, a memória, a reflexão e a emoção” (BRASIL, 2018, p.196).

Com base no que foi apresentado, esta pesquisa propõe-se incluir a dramatização nas atividades teatrais, pois conjectura-se uma ótima oportunidade para explorar o conceito de Educação Financeira, visto que "O drama na educação, como linguagem, potencializa o desenvolvimento de múltiplas facetas” (GARCIA et al., 2006, p.87). 
A dramatização do ponto de vista de Vigotski (2009), referente a obra “A criação teatral na idade escolar", afirma:

A dramatização é a que está mais próxima da criação literária infantil. Juntamente com a criação verbal, a dramatização, ou a encenação teatral, representa o tipo de criação infantil mais frequente e difundido. Isso é compreensivo porque ela está mais próxima da criança, o que se explica por dois momentos principais. Em primeiro lugar, o drama baseado na ação - na ação realizada pela criança - é mais íntimo, mais ativo e relaciona de maneira direta a criação artística com vivência pessoal (Vigotski, 1009, p.97).

Por fim, este artigo trata da Educação Financeira como tema transversal, conforme definido nos Parâmetros Escolares Nacionais, o qual tem o objetivo de dar sentido social amplo a procedimentos e conceitos, extrapolando os ambientes escolares para dar ao jovem conhecimento e uma visão mais ampla do ambiente em que vive, ou seja, aprender na realidade e da realidade. Dessa forma, deve-se trabalhar o conteúdo por meio de atividades que promovam o envolvimento total dos alunos, considerando os aspectos físicos, psicossociais, afetivos e morais. Uma das formas é o desenvolvimento prático de atividades, pois desperta e estimula o interesse estudantil. Nesta pesquisa, são apresentadas como uma das possibilidades para essa experiência e aprendizado, as artes teatrais, em consonância com a pedagogia de projetos.

\section{Delineamento metodológico}

Este artigo apresenta um estudo de campo com duas turmas do $2^{\circ}$ ano do ensino médio do Colégio Estadual Dr. Félix Miranda, situado na cidade de Campos dos Goytacazes, Estado do Rio de Janeiro. Esta pesquisa se baseia na criação e aplicação de uma experimentação, tendo o Teatro como recurso principal. As atividades foram inspiradas nos livros Educação Financeira nas Escolas, já mencionados neste artigo.

O estudo utilizou ferramentas quantitativas e qualitativas de coleta de dados, enraizadas em uma posição epistemológica que reconhece a importância de localizar a pesquisa dentro de um contexto social, cultural e histórico particular.

A experimentação didática se baseia em duas atividades: A primeira e principal foi uma encenação teatral sobre taxas de juros no âmbito social e familiar. Na segunda atividade, uma situação problema envolvendo o impacto da inflação somente no ambiente familiar, sendo esta uma concepção da primeira atividade.

Os dados investigativos foram coletados em dois momentos, sendo a entrevista inicial mais exploratória, para saber o conhecimento dos estudantes sobre Educação Financeira e o 
segundo, no final das atividades, orientada pelos insights. O Quadro 1 mostra as ações da pesquisa com datas e descrição.

Quadro 1 - Ações da Pesquisa.

\begin{tabular}{|c|c|c|l|}
\hline Ações da Pesquisa & Data & $\begin{array}{l}\text { Aula }- \\
\text { 50 min }\end{array}$ & \multicolumn{1}{|c|}{ Descrição } \\
\hline $\begin{array}{c}\text { Apresentação do projeto } \\
\text { didático }\end{array}$ & $12 / 03 / 2019$ & 2 & $\begin{array}{l}\text { Esclarecimentos sobre as autorizações } \\
\text { dos responsáveis (pais e direção). }\end{array}$ \\
\hline $\begin{array}{c}\text { Questionário Investigativo } \\
\text { Inicial }\end{array}$ & $14 / 03 / 2019$ & 2 & $\begin{array}{l}\text { Apresentado o material didático: } \\
\text { (BRASIL, 2013); (BRASIL, 2014a) e } \\
\text { (BRASIL, 2014b) e aplicação inicial } \\
\text { sobre Taxa de Juros com análises e } \\
\text { discussões pautadas nos textos do Livro } \\
\text { 1 (BRASIL, 2013, p.70-77). }\end{array}$ \\
\hline Atividade 1 & $19 / 03 / 2019$ & 2 & $\begin{array}{l}\text { Questionário sobre a temática da } \\
\text { pesquisa para analisar o nível de } \\
\text { conhecimento dos alunos antes das } \\
\text { atividades. }\end{array}$ \\
\hline Pré-Atividade 2 & $20 / 03 / 2019$ & 2 & $\begin{array}{l}\text { Taxa de Juros - Teatro - Dramatização } \\
\text { de Uma Situação de Vida Comum. }\end{array}$ \\
\hline Atividade 2 & $21 / 03 / 2019$ & 2 & $\begin{array}{l}\text { Aula expositiva dialogada para reflexão e } \\
\text { explicação. }\end{array}$ \\
\hline Questionário Investigativo & $05 / 04 / 2019$ & 2 & $\begin{array}{l}\text { Aplicação da prática que simula uma } \\
\text { situação problema na vida de uma } \\
\text { família. Matematização da reflexão } \\
\text { gerada na Atividade 1. }\end{array}$ \\
\hline Final & $27 / 03 / 2019$ & $\begin{array}{l}\text { Questionário final sobre as opiniões dos } \\
\text { estudantes em relação ao trabalho } \\
\text { desenvolvido ao longo da pesquisa, a } \\
\text { importância da Educação Financeira, o } \\
\text { material didático utilizado e as atividades } \\
\text { aplicadas. }\end{array}$ \\
\hline
\end{tabular}

Fonte: Elaborado pelos autores.

Todas as Atividades tiveram a duração de 2 aulas com a participação de 40 estudantes.

Como o Teatro é atividade cerne da experimentação, alinhamos a pesquisa no formato do tipo Pesquisa-Ação, pois conjecturamos ser apropriado em vista as características desse tipo de pesquisa. Para Chizzotti (2018), a Pesquisa-Ação tem a seguinte definição:

\footnotetext{
Pesquisa-ação se propõe a uma ação deliberada visando uma mudança no mundo real, comprometida com um campo restrito, englobando em um projeto mais geral e submetendo-se a uma disciplina para alcançar os efeitos do conhecimento (CHIZZOTTI, 2018, p.54).
}

Vale ressaltar que esse tipo de pesquisa possui características insólitas que a destaca dos outros tipos de pesquisa. Azevedo e Abib (2013) apresentam esse tipo de pesquisa como construtivista, situacional, prática, sistemática e cíclica. Consequentemente essa modalidade de 
pesquisa deve ser, rigorosamente, empírica e reflexiva (ou interpretativa). Ela precisa envolver as pessoas como participantes ativas no processo de ensino-aprendizado.

Provido da compreensão dos princípios subjacentes da Pesquisa-Ação, esta pesquisa: 1 - foi fundamentada na experiência vivida dos estudantes; 2 - foi desenvolvida em parceria; 3 abordou problemas significativos; 4 - trabalhou com alunos em vez de estudá-los; 5 desenvolveu novas formas de ver/teorizar o ensino e aprendizagem da Educação Financeira através do Teatro; 6 - deixou uma base para as proficiências, em particular a tomada de decisão, para impactar o ensino e aprendizagem e, mais importante, as disposições do aluno durante o processo.

As descrições específicas das atividades utilizadas na experimentação foram:

Questionários Investigativos - Nesta pesquisa optou-se por uma estrutura de questionamento com perguntas fechadas, permitindo que essas se encaixem em categorias prédecididas. Nesse sentido, para a prática da pesquisa de ação participativa, foram elaborados dois questionários investigativos denominados por Questionário Investigativo Inicial (Quadro 2), aplicado antes da experimentação e Questionário Investigativo Final (Quadro 3) aplicado ao término da experimentação. O Questionário Investigativo Inicial tem como objetivo entender e analisar o perfil dos pesquisados quanto ao nível de conhecimento e entendimento sobre assuntos relacionados à Educação Financeira. O Questionário Investigativo Final visa uma análise sobre o nível de conhecimento obtido após a experimentação e ainda as opiniões referentes à metodologia adotada.

Quadro 2 - Detalhes do Questionário Investigativo Inicial.

\begin{tabular}{|l|l|}
\hline \multicolumn{1}{|c|}{ Questionamento } & \multicolumn{1}{c|}{ Opções de respostas } \\
\hline $\begin{array}{l}\text { 1- Você se sente seguro para efetuar cálculos } \\
\text { envolvendo porcentagens, juros, taxas e descontos? }\end{array}$ & $\begin{array}{l}\text { ( ) Sim; } \\
\text { ( ) Mais ou menos; } \\
\text { () Não; }\end{array}$ \\
\hline $\begin{array}{l}\text { 2- Na sua opinião, o conhecimento matemático } \\
\text { pode ajudar a lidar melhor com o dinheiro? }\end{array}$ & $\begin{array}{l}\text { ( ) Sim; } \\
\text { ( ) Mais ou menos; } \\
\text { ( ) Não; }\end{array}$ \\
\hline $\begin{array}{l}\text { E- Qual o grau de importância que você atribui à } \\
\text { Educação Financeira nas escolas? }\end{array}$ & $\begin{array}{l}\text { ( ) Indispensável; } \\
\text { ( ) Importante; } \\
\text { ( ) Pouco importante; }\end{array}$ \\
\hline $\begin{array}{l}\text { ( ) Gastar sempre o mínimo possível; } \\
\text { familiar e doméstico? }\end{array}$ & $\begin{array}{l}\text { ( ) Ter o detalhamento dos valores dos gastos } \\
\text { mensais, como aluguel, parcelamentos, entre outros; } \\
\text { ( ) Ter o detalhamento exato e contínuo dos ganhos } \\
\text { (receita) e gastos mensais; } \\
\text { ( ) Outros: }\end{array}$ \\
\hline $5-$ Como você organiza seus gastos? & $\begin{array}{l}\text { ( ) Não organizo pois não possuo renda; } \\
\text { ( ) Não organizo, pois tenho acesso a valores } \\
\text { financeiros muito baixos; } \\
\text { () Me organizo somente para os gastos mais altos; }\end{array}$ \\
\hline
\end{tabular}




\begin{tabular}{|c|c|}
\hline & $\begin{array}{l}\text { () Registro em planilhas todos os meus gastos } \\
\text { mensais; } \\
\text { () Outros: }\end{array}$ \\
\hline 6-O que você entende por "compra a prazo"? & $\begin{array}{l}\text { ( ) Algo vantajoso, pois em geral não compromete, de } \\
\text { forma significativa, o orçamento mensal; } \\
\text { ( ) Uma forma facilitada de adquirir um produto, pois } \\
\text { dificilmente se tem o valor todo para a compra } \\
\text { imediata; } \\
\text { ( ) Uma modalidade de compra que, na maioria das } \\
\text { vezes, implica em pagar taxas extras, pois existe um } \\
\text { custo para se ter o produto antecipadamente; } \\
\text { ( ) Outros: }\end{array}$ \\
\hline 7 - O que você entende por "juros"? & $\begin{array}{l}\text { ( ) Uma tarifa cobrada mensalmente pelo Banco; } \\
\text { ( ) Um imposto cobrado nas contas; } \\
\text { ( ) Uma tarifa cobrado pelo pagamento atrasado das } \\
\text { faturas do cartão de crédito somente; } \\
\text { ( ) Um desconto nas compras; } \\
\text { () Aluguel pago pelo uso do dinheiro. }\end{array}$ \\
\hline $\begin{array}{l}8 \text { - Como acabar com as dívidas de uma pessoa que } \\
\text { já está endividada? }\end{array}$ & $\begin{array}{l}\text { ( ) Comprar à vista somente; } \\
\text { ( ) Utilizar mais o cartão de crédito, pois com ele } \\
\text { pode-se organizar os gastos através das faturas } \\
\text { mensais; } \\
\text { ( ) Fazer outros empréstimos; } \\
\text { ( ) Fazer um planejamento financeiro e priorizar o } \\
\text { pagamento das dívidas, evitando gastos supérfluos; } \\
\text { ( ) Comprar em nomes de terceiros. }\end{array}$ \\
\hline 9 - O que você entende por inflação? & $\begin{array}{l}\text { ( ) Taxa de juros cobrados pelos bancos; } \\
\text { ( ) Aumento dos preços de produtos e serviços que } \\
\text { causa a redução do poder de compra; } \\
\text { ( ) Diminuição dos preços de produtos e serviços que } \\
\text { causa o aumento do poder de compra; } \\
\text { ( ) Lucro gerado por empresas; } \\
\text { ( ) Outros: }\end{array}$ \\
\hline
\end{tabular}

Fonte: Elaborado pelos autores.

Quadro 3 - Detalhes do Questionário Investigativo Final.

\begin{tabular}{|c|c|}
\hline Questionamento & Opções de respostas \\
\hline $\begin{array}{l}1 \text { - Após a realização desse experimento, você se } \\
\text { sente mais capaz de lidar com assuntos } \\
\text { financeiros? }\end{array}$ & $\begin{array}{l}\text { () Sim; } \\
\text { () Mais ou menos; } \\
\text { () Não; }\end{array}$ \\
\hline $\begin{array}{l}2 \text { - Você acredita que se a Educação Financeira } \\
\text { fosse abordada com maior ênfase no ambiente } \\
\text { escolar as pessoas teriam posturas mais conscientes } \\
\text { em relação à gestão do dinheiro? }\end{array}$ & $\begin{array}{l}\text { ( ) Sim; } \\
\text { ( ) Não; }\end{array}$ \\
\hline $\begin{array}{l}3 \text { - Em relação à atividade proposta: dramatização } \\
\text { sobre juros, impostos, inflação e investimentos } \\
\text { (peça teatral), reforçado com a situação problema } \\
\text { no orçamento familiar, foi significativo na sua } \\
\text { aprendizagem? }\end{array}$ & $\begin{array}{l}\text { ( ) Sim; } \\
\text { ( ) Não; } \\
\text { Justifique: }\end{array}$ \\
\hline $\begin{array}{l}4 \text { - Como você classifica os livros da coleção } \\
\text { EDUCAÇÃO FINANCEIRA NAS ESCOLAS, } \\
\text { utilizados nos círculos das discussões? }\end{array}$ & $\begin{array}{l}\text { () Muito atrativos; } \\
\text { () Medianos; } \\
\text { () Pouco atrativos; }\end{array}$ \\
\hline $\begin{array}{l}5 \text { - Dos assuntos abordados nesta experimentação, } \\
\text { assinale o que mais chamou sua atenção. }\end{array}$ & $\begin{array}{l}\text { () Taxas de juros; } \\
\text { () Inflação; } \\
\text { () Impostos; } \\
\text { () Investimentos }\end{array}$ \\
\hline
\end{tabular}




\begin{tabular}{|l|l|}
\hline & Justifique: \\
\hline & Problema 1: Uma família precisou obter um \\
& empréstimo no valor de R $\$ 200,00$, com juros de $15 \%$ \\
ao mês, pergunta-se: ao final de 2 meses, & considerando que não houve pagamento algum, a \\
6-Resolução de Probemas: & dívida dessa família será de: \\
Problema 1 - sobre taxa de juros. & Problema 2: Supondo que a inflação no país seja de \\
Problema 2 - sobre inflação. & $8 \%$ em determinado ano, um salário de R $\$ 3000,00$ \\
& deve aumentar em quanto para que seja mantido o \\
& poder de compra do trabalhador? \\
\hline
\end{tabular}

Fonte: Elaborado pelos autores.

Atividade 1 - Se baseia na aplicação de uma atividade de dramatização de uma situação de vida comum, utilizando o Teatro como ferramenta pedagógica. As competências desta atividade são voltadas para o entendimento do valor do dinheiro e nas tomadas de decisões bem fundamentadas sobre empréstimos e poupança, atuando como um cidadão consciente. $\mathrm{O}$ objetivo específico dessa atividade está na aplicação do conceito de taxas de juros na prática instigando a tomada de decisão e na percepção dos estudantes das possíveis consequências que podem ocorrer devido à falta de conhecimento do assunto. Após o círculo de discussões sobre taxa de juros, foi proposta a culminância da primeira atividade. A referida foi inspirada na sugestão do livro Educação Financeira nas Escolas Bloco 1 (BRASIL, 2013), mostrado na Figura 1 e que traz o seguinte texto:

Figura 1 - Fonte específica para a Atividade 1. 


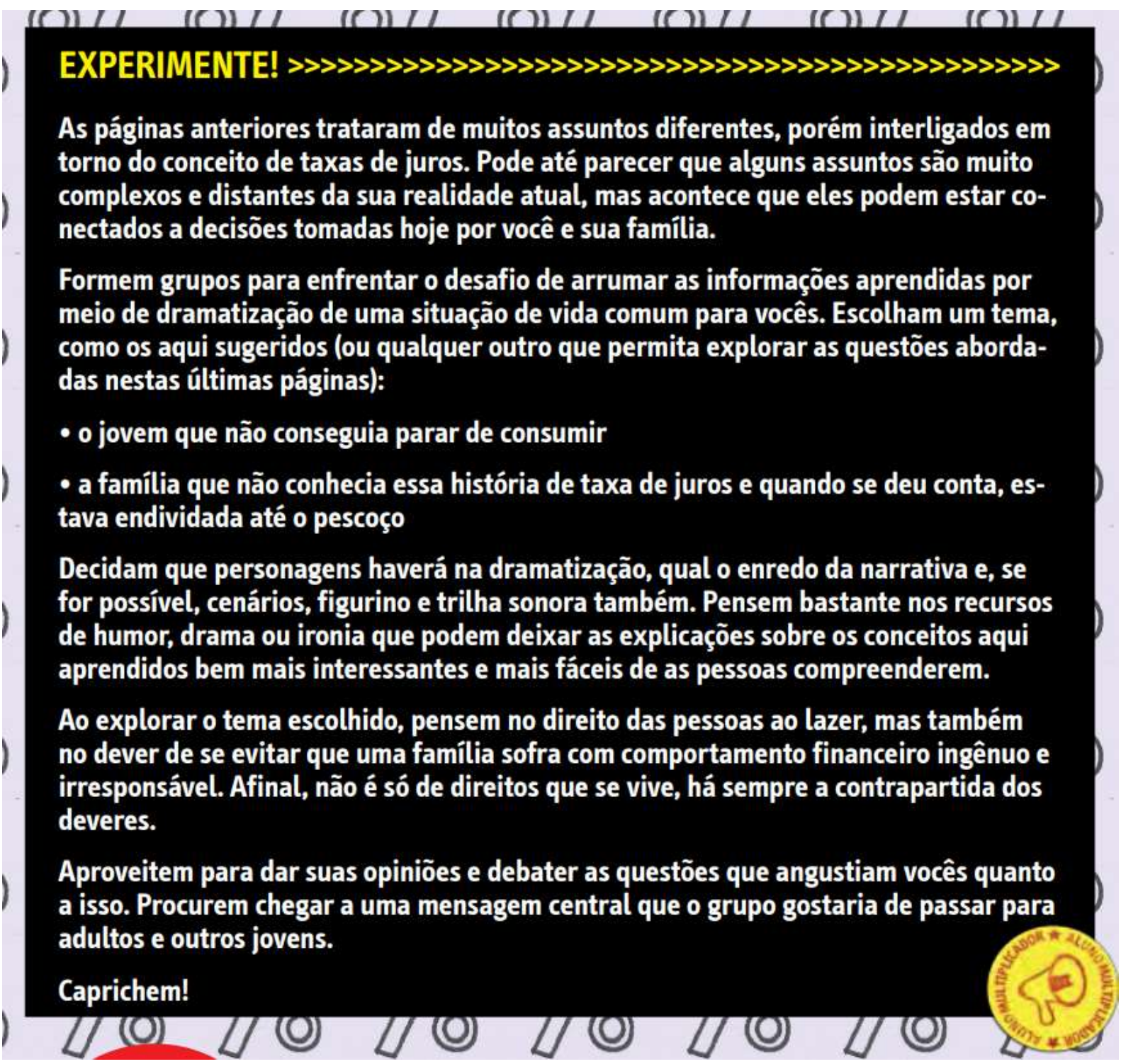

Fonte: (BRASIL, 2013, p.77)

Os alunos se organizaram em 4 grupos conforme segue: grupo 1 levou uma temática que envolvia uma família bem-sucedida. Embora a situação financeira fosse confortável, apareceram diversos problemas em virtude de uma situação bastante corriqueira, inclusive em famílias com um poder aquisitivo menor, que é a compulsão por compras. Isso os levou a recorrer a empréstimos com agiotas, promovendo cenas dramáticas em prol do desenvolvimento da educação emocional e financeira.

O grupo 2 encenou uma situação de dois amigos de infância, um jovem que não sabe administrar o dinheiro e uma estudante empresária. Com o passar do tempo, se encontram e percebem que ela se tornou bem-sucedida e ele um rapaz endividado. O drama é norteado na recuperação financeira do jovem endividado, gerando soluções financeiras viáveis para sua recuperação. 
O terceiro grupo apresentou uma situação envolvendo repasses de aumentos ao consumidor, mostrando a visão do agricultor e do consumidor final em um supermercado. Com esse tema foi necessário utilizar conceitos mais abrangentes como inflação, mudanças nas taxas de juros e o impacto destas variáveis sobre o mercado. Essa equipe trabalhou a temática e compartilhou com os colegas como o aumento ou a queda das taxas de juros podem afetar a psicologia do consumidor e por outro lado os negócios.

O quarto grupo encenou sobre uma família que desconhecia a taxa de juros e ficou muito endividada. Em um contexto similar ao da primeira equipe, aqui as pessoas são atraídas por propagandas e promoções de lojas. Depois do termo dívida, a palavra juros, talvez, seja a mais comum quando se trata do endividamento. A família adquiriu empréstimos a juros altíssimos, gerando uma dramatização criativa, promovendo o crescimento da personalidade e aprendizagem dos estudantes sobre o amplo conceito de juros no contexto social.

Atividade 2 - É dividida em duas etapas e se baseia numa situação problema envolvendo inflação no contexto familiar. A primeira etapa é uma apresentação expositiva e dialogada sobre impostos, bens e serviços públicos com análises e discussões pautadas nos textos do livro (BRASIL, 2014a, p.68-75), apresentado na Figura 2. Em seguida é apresentado o vídeo "A origem dos Impostos" (GEFE-SP, 2019). O objetivo está na contextualização dos conceitos financeiros, preparando os estudantes para a próxima etapa. A segunda etapa simula uma situação problema relacionada à inflação na vida de uma família. Entendendo que as decisões financeiras da família pressupõem acordo entre pessoas; a atividade foi realizada em dupla. O objetivo da segunda etapa, visa estimular o estudante com a tomada de decisão através da matemática financeira, além de fazer uma elucubração da primeira atividade, o Teatro.

Figura 2 - Fonte específica para a Atividade 2.

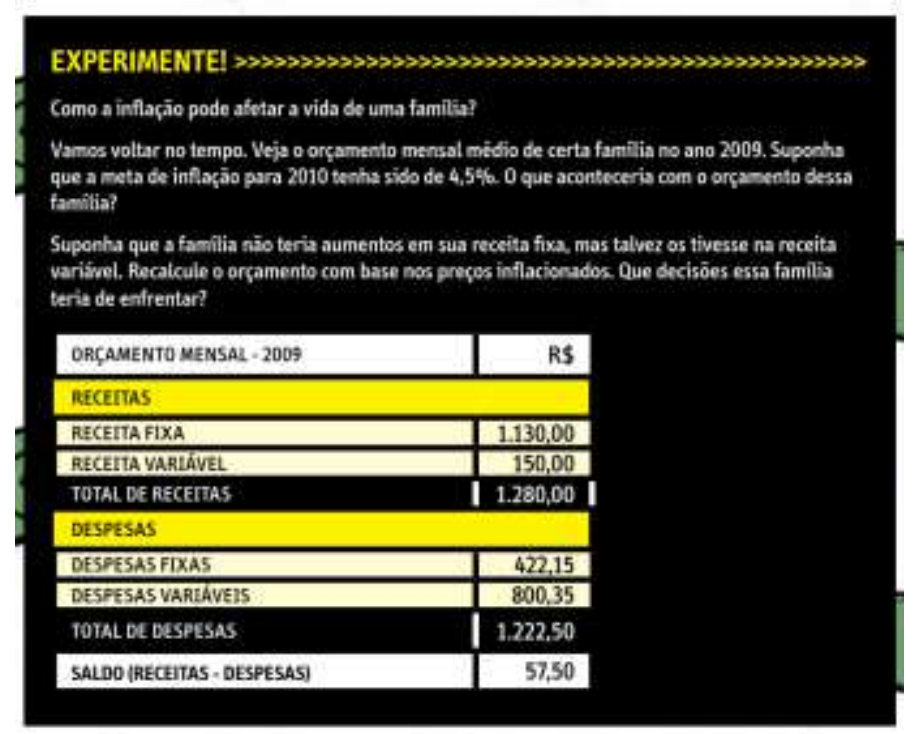

Fonte: (BRASIL, 2014a, p.76)

Revista Interinstitucional Artes de Educar. Rio de Janeiro, V.7, N.3 - pág. 1528-1554 set-dez de 2021: "Dossiê Relatos de experiências e produção acadêmica” - DOI: https://doi.org/10.12957/riae.2021.52245 
Por fim, com base no que foi apresentado nesta metodologia, propõe-se enaltecer a dramatização nas atividades teatrais, visando uma ampla e considerável conscientização dos estudantes a respeito da Educação Financeira, pois acredita-se que este tipo de modalidade seja uma excelente oportunidade artística para promover o desenvolvimento da imaginação, crescimento da personalidade e facilitador da aprendizagem dos estudantes no tema proposto.

\section{Descrição e análise dos resultados}

Neste artigo serão abordados alguns questionamentos de maior relevância na pesquisa. Serão apresentados alguns dados quantitativos referentes aos questionários investigativos e alguns dados qualitativos referentes as observações dos pesquisadores e registros dos próprios estudantes.

\section{Questionário Investigativo Inicial}

A primeira pergunta do questionário investigativo inicial foi elaborada a fim de averiguar a segurança dos pesquisados quanto aos cálculos envolvendo conceitos de Matemática Financeira. Das 40 respostas, 72,5\% apresentaram insegurança na utilização de tais conceitos. Quando questionados sobre a importância de conteúdos de matemática para auxiliarem nas questões financeiras, todos os pesquisados responderam positivamente.

Em seguida, os estudantes foram questionados sobre o conceito de "compra a prazo". Uma compra pode ter o significado de tomar posse de um determinado ativo, item ou direito, pagando uma quantia predeterminada para que a transação seja concluída com êxito. Em outras palavras, é uma troca de dinheiro por um determinado bem ou serviço.

As respostas deste questionamento despertaram um alerta na pesquisa. A maioria dos pesquisados $(52,5 \%)$ entendem "compra a prazo" como facilitador em adquirir um produto, sem levar em consideração os possíveis reajustes nas parcelas. Os estudantes precisam conhecer desde cedo os custos envolvidos no ato de comprar. Nessa fase, é muito importante entender conceitos sobre as taxas de juros e os custos associados a essas operações. Por esse motivo, buscar-se-á o conceito que os alunos têm sobre juros. Na Figura 3 é possível verificar que apenas $12 \%$ entendem o conceito correto de juros. Há quem afirme que nessa fase da educação básica alguns conceitos podem ser difíceis para o entendimento do aluno, porém ao iniciar a educação financeira desde cedo, pode-se sair do complexo para o familiar. Os conceitos evoluem e amadurecem, ao longo do tempo, juntamente com o desenvolvimento cognitivo do aluno e a natureza e sofisticação do conteúdo matemático. 
Figura 3 - Questionário Investigativo inicial: "O que você entende por juros?"

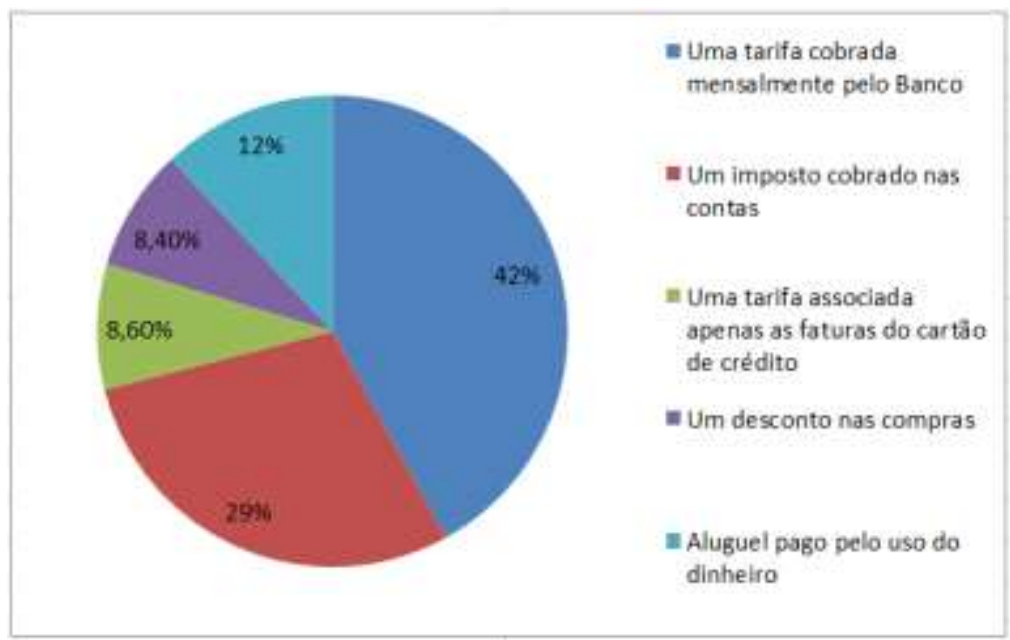

Fonte: Dados da pesquisa.

Entretanto, questionados sobre o conceito de inflação, 66\% apresentaram o conhecimento sobre a definição formal deste conceito, contudo, $34 \%$ não entendem corretamente o conceito de inflação, como mostra a Figura 4. Constata-se, com base na análise dos dados apresentados, que o conceito de inflação é entendido pelos pesquisados de um modo geral, porém existe uma certa dificuldade em conceituá-la.

Figura 4 - Questionário Investigativo inicial: “O que você entende por inflação?”

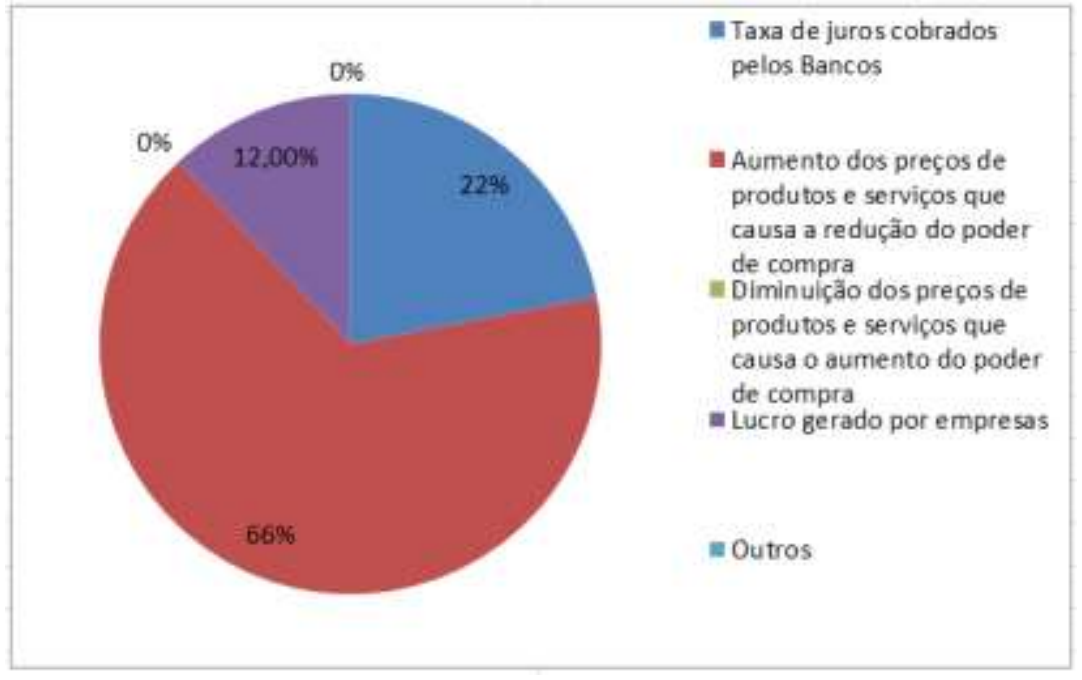

Fonte: Dados da pesquisa.

Se os estudantes desenvolverem boas habilidades financeiras, desde cedo, provavelmente, estarão prontos para os desafios financeiros da vida adulta. Oferecer-lhes uma boa base e ensinar-lhes sobre o dinheiro é fundamental para o desenvolvimento pessoal. 
Mostrar aos jovens conceitos básicos, como orçamentar, gastar e poupar tenderá a estabelecer bons hábitos financeiros para a vida própria. Por consequência, este questionário além de cumprir os objetivos iniciais propostos, externou-se um excelente espaço para gerar discussões e reflexões com os estudantes sobre a Educação Financeria.

\section{Atividade 1 - Teatro}

Nesta experimentação, teatralizamos juntamente com os estudantes quatro cenas dramáticas. Nesta atividade prática, os estudantes deixam de ser apenas espectadores e se tornam protagonistas de suas enunciações e teatralidades.

O grupo 1 inicia o roteiro com a seguinte narrativa: " $A 1$ " é mulher independente, trabalha em uma das maiores empresas do país, ganha muito bem e seu casamento é invejável, porém seu único problema é o impulso na hora das compras. "Al” está indo para o trabalho quando passa em frente à loja de "A2" e se encanta com o que vê. Após essa narrativa, a dramatização conta a história de um casal que vê o seu relacionamento se desfazer por conta de endividamentos originados pelas compras por impulso, por parte da esposa, que os motivaram a recorrer a empréstimos com elevadas taxas de juros. Os membros do grupo improvisaram a ação e dialogaram para explorar o conteúdo, "usando elementos dramáticos para dar forma e significado à experiência” (DAVIS; BEHM, 1978, p.11).

Nesta primeira cena, o grupo pôde vivenciar e mostrar, de forma prática, que quando um indivíduo se entrega à compra por impulso, não é apenas difícil para o bolso a curto prazo, mas o hábito impede as boas práticas financeiras após um determinado tempo. Foi possível observar a interação entre os que apresentavam e assistiam na busca de decisões financeiras conscientes.

O grupo 2 conta a história de dois amigos de infância. Um identificado como o Jovem que fica endividado e uma estudante empresária. Por posturas diferentes na administração dos recursos financeiros, os dois veem suas vidas tomarem rumos totalmente diferentes. Ele, um rapaz com muitas dívidas, tendo que recorrer a empréstimos bancários com taxas de juros altas e ela, uma moça sem dívidas e bem-sucedida. Além dessas personagens, a peça conta com o Gerente do Banco e um narrador. Esta cena foi marcada pela iniciativa do grupo na busca por soluções viáveis para a recuperação financeira do jovem, através de formas de investimentos, empréstimos com juros menores, entre outros, posicionando o Gerente do Banco como o pivor das discussões. O grupo procurou demonstrar que o conhecimento prévio sobre juros pode levar 
o indivíduo a tomar boas decisões financeiras que porventura, podem refletir positivamente no futuro.

O grupo 3 mostrou a dinâmica dos repasses de aumentos ao consumidor. A dramatização conta com um narrador, Agricultor, Revendedor, Caixa de Supermercado e Consumidor. A história se passa em dois cenários distintos - fazenda e supermercado. Os diálogos entre as personagens evidenciam inconformismo em virtude da alta dos preços, gerando reflexões muito interessantes. Nesta cena, os estudantes exploraram os conceitos de juros e inflação, apresentando todos possíveis pontos de vista do mercado nacional. Na atuação foi percebido utilização coerente da porcentagem e do cálculo inflacionário através de taxas de juros atreladas ao Índice Nacional de Preços ao Consumidor Amplo (IPCA).

O grupo 4 acatou uma das sugestões de dramatização do livro base cujo título era “ $A$ família que não conhecia essa história de taxa de juros e quando se deu conta estava endividada até o pescoço". A interpretação contou com personagens identificadas como pai, mãe, filho, filha, vendedora e Gerente do Banco. O enredo gira em torno de uma família em que todos os integrantes se deixam seduzir por promoções de lojas, ocasionando uma crítica múltua, embora todos da família praticassem a mesma atitude. A família entra em um estágio de decadência financeira e se vê obrigada a recorrer a empréstimos financeiros com juros altíssimos, proporcionando um drama totalmente criativo. De acordo com Garcia (2006), “o primeiro propósito do drama criativo é promover o crescimento da personalidade e facilitar a aprendizagem dos participantes, mais que formar atores para o palco". Esta cena de natureza dramática conduziu os envolvidos momentos de experiência direta, transcendendo o conhecimento conceitual de juros e suas aplicações.

Ao término da Atividade 1, mesmo aqueles que se recusaram a participarem, conseguiram interagir com as situações apresentadas pelos grupos. Uma das lições financeiras mais importantes para compartilhar é explicar conceitos sobre taxas de juros e como elas funcionam. O Teatro, como recurso pedagógico, foi possível analisar através das encenações, que os estudantes consentiram os conceitos sobre a Educação Financeira. Com essa atividade pudemos perceber uma postura reflexiva dos estudantes em relação as problematizações apresentadas. Foi possível ver a interação de todos os estudantes na apresentação das cenas. Trabalhar com o Teatro pode fornecer aos participantes insights importantes para auxiliá-los em seus estudos, ajudá-los na habilidade para que possam interagir uns com os outros e compartilhar seu atual nível de pensamento crítico e a sofisticação da linguagem que eles usam. 


\section{Atividade 2 - Matematização da reflexão gerada pelo Teatro}

Esta atividade (Figura 2) visa obter o registro dos estudantes em uma situação problema envolvendo o contexto familiar, onde a competência está voltada para verificação ou confirmação dos conhecimentos adquiridos nas encenações teatrais. O objetivo desta atividade baseia-se na estimulação dos estudantes nas tomadas de decisões, com uma prática envolvendo o impacto da inflação no orçamento familiar.

A seguir é apresentado algumas respostas dos alunos em relação a Atividade 2. A resposta do aluno A3 é mostrada na Figura 5. Observa-se certa dificuldade em definir o aumento das despesas, uma vez que o valor correto é $\mathrm{R} \$ 145,00$. Contudo, a conclusão em relação ao saldo negativo está correta. Deve-se ressaltar, ainda, a conscientização dos alunos em relação à necessidade do envolvimento da família para solucionar tal problema.

Figura 5 - Atividade 2: registro do estudante A3.

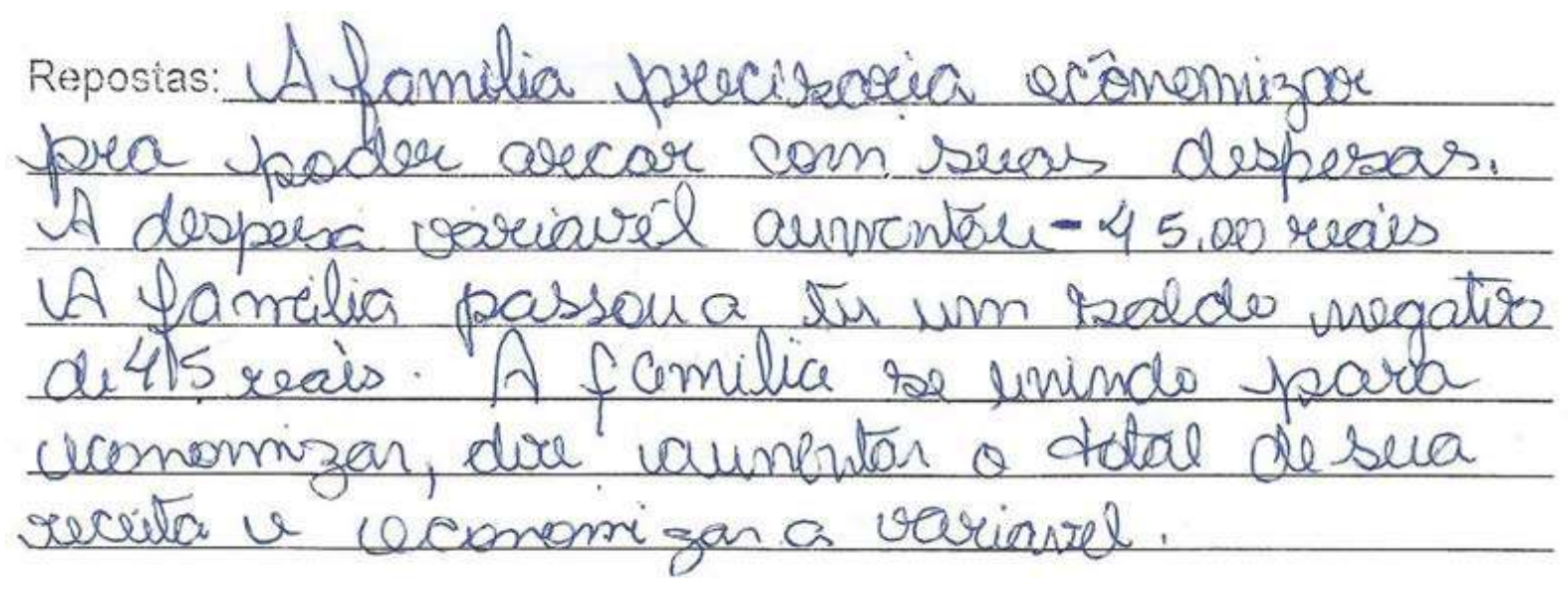

Fonte: Dados da pesquisa.

“A família precisaria ecônomizar pra poder arcar com suas despesas. A despesa variável aumentou - 45,00 reais. A família passou a ter um saldo negativo de 45 reais. A família se unindo para economizar, deve aumentar o total de sua receita e economizar a variavel" (ALUNO A3).

Em geral, a turma teve êxito em suas considerações, indo ao encontro dos conceitos da Educação Financeira que reje uma vida financeira saudável. Através da conscientização e dos conhecimentos em matemática financeira adquiridos nas encenações, os estudantes puderam tomar decisões coerentes, como mostra a Figura 6 por exemplo. 
Figura 6 - Atividade 2: registro do estudante A4.

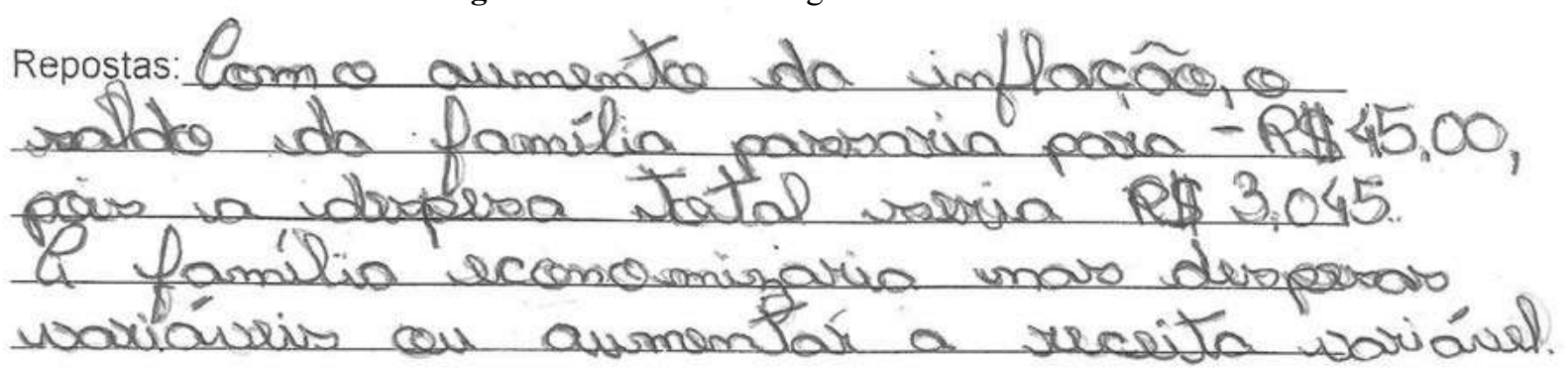

Fonte: dados da pesquisa.

"Com o aumento da inflação, o saldo da família passaria para - $\mathrm{R} \$ 45,00$ pois a despesa total seria $\mathrm{R} \$ 3.045$. a Família economizaria nas despesas variáveis ou aumentar a receita variável" (ALUNO A4).

Por fim, vimos no teatro, em especial, na dramatização, uma perfeita oportunidade para criar reflexões e explorar os conceitos da Educação Financeira. Ao ofertarmos as atividades cênicas com os estudantes, estamos, de fato, oferecendo uma possibilidade para as suas próprias enunciações através de suas vivências, numa perspectiva de interação social, em meios a problematizações contextualizadas. Para Vygotsky (1989), pela interação social, o aluno tem acesso aos modos de pensar e agir correntes em seu meio. A cultura compartilha as formas de raciocínio, as diferentes linguagens (como a matemática financeira), costumes, emoções, entre outros.

\section{Questionário Investigativo Final}

Após a realização das etapas citadas anteriormente, chegou o momento do questionário investigativo final. O objetivo foi obter o feedback dos estudantes a respeito da experimentação e avaliar seus conhecimentos adquiridos ao final do experimento.

$\mathrm{O}$ primeiro questionamento está relacionado à confiança em lidar com assuntos financeiros. A maioria dos pesquisados (63\%) informou estarem mais confiantes em lidar com assuntos financeiros após a pesquisa. Questionados: "se a Educação Financeira fosse abordada com maior ênfase no ambiente escolar, as pessoas teriam posturas mais conscientes, no futuro, em relação à gestão do dinheiro", o resultado foi unânime, 100\% dos pesquisados marcaram a opção sim.

Em relação ao material didático trabalhado na pesquisa, 88,5\% afirmaram ser muito atrativo e os outros $11,5 \%$ declararam o material mediano. No próximo questionamento, o interesse da pesquisa foi saber do estudante qual dos assuntos abordados nos roteiros gerados 
nas encenações teatrais, despertou mais à atenção dele. A Figura 7 apresenta praticamente uma distribuição homogênea dos assuntos escolhidos. Esta diversificação de escolhas e identificações sobre os temas discutidos nas encenações, corrobora para a promoção do conhecimento mais diversificado, podendo ser este mais um potencial da dramaturgia como ferramenta pedagógica.

Em relação a este conhecimento diversificado, Dolci (2004), apresenta um estudo a respeito dos benefícios que o Teatro traz para os educandos, tendo como base uma pesquisa empírica sobre “A Influência do Teatro no Desenvolvimento do Aluno”, e afirma:

Utilizar a arte cênica aliada à educação, oportuniza aos estudantes um conhecimento diversificado e lúdico, favorecendo a liberdade de expressão, permitindo, assim, o desenvolvimento do aluno na sua totalidade. O Teatro amplia o horizonte dos alunos, melhora sua auto-imagem e colabora para torná-los mais críticos e abertos ao mundo que os cercam. O aluno fica mais receptivo e aplica simultaneamente a linguagem escrita, oral, dramática e corporal. (DOLCI, 2004, p.73)

Figura 7 - Questionário Investigativo Final: “Qual assunto mais despertou a sua atenção nas encenações?”

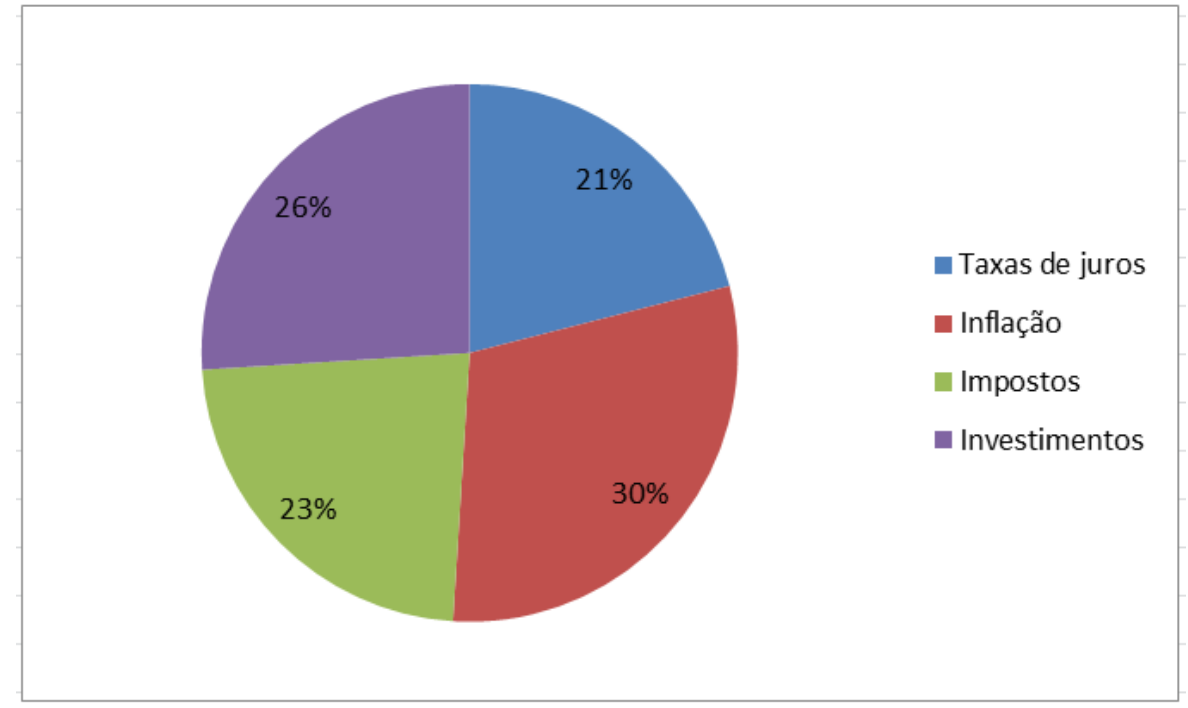

Fonte: dados da pesquisa.

As Figuras 8 e 9 mostram os resultados dos problemas relacionados à matemática financeira que apesar de ser tratada, sutilmente, está diretamente ligada aos assuntos trabalhados na experimentação da pesquisa. Deseja-se com estas duas próximas questões, não somente avaliar os conhecimentos obtidos experimentalmente mas também promover uma percepção de relação entre a experimentação e a matemática financeira que, neste trabalho, não foi protagonista, mais uma ferramenta importante e últil para a difusão da Educação Financeira nas aulas de matemática. 
Figura 8 - Questionário Investigativo Final: Problema sobre taxa de juros.

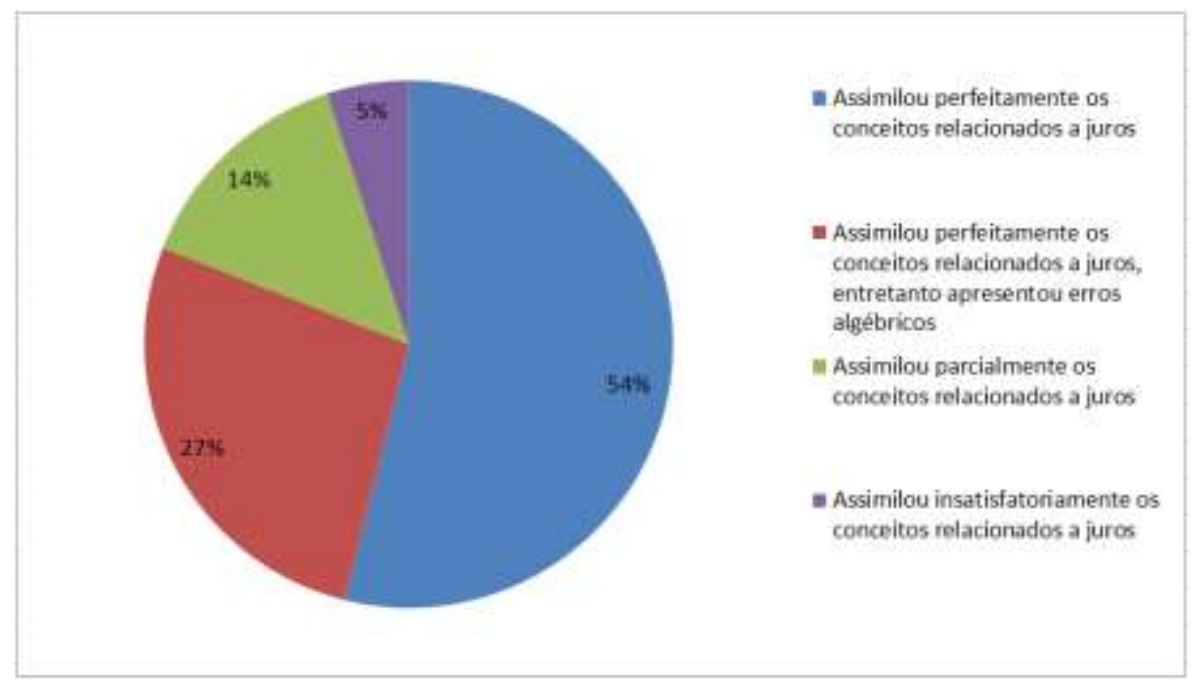

Fonte: dados da pesquisa.

Figura 9 - Questionário Investigativo Final: Problema sobre inflação.

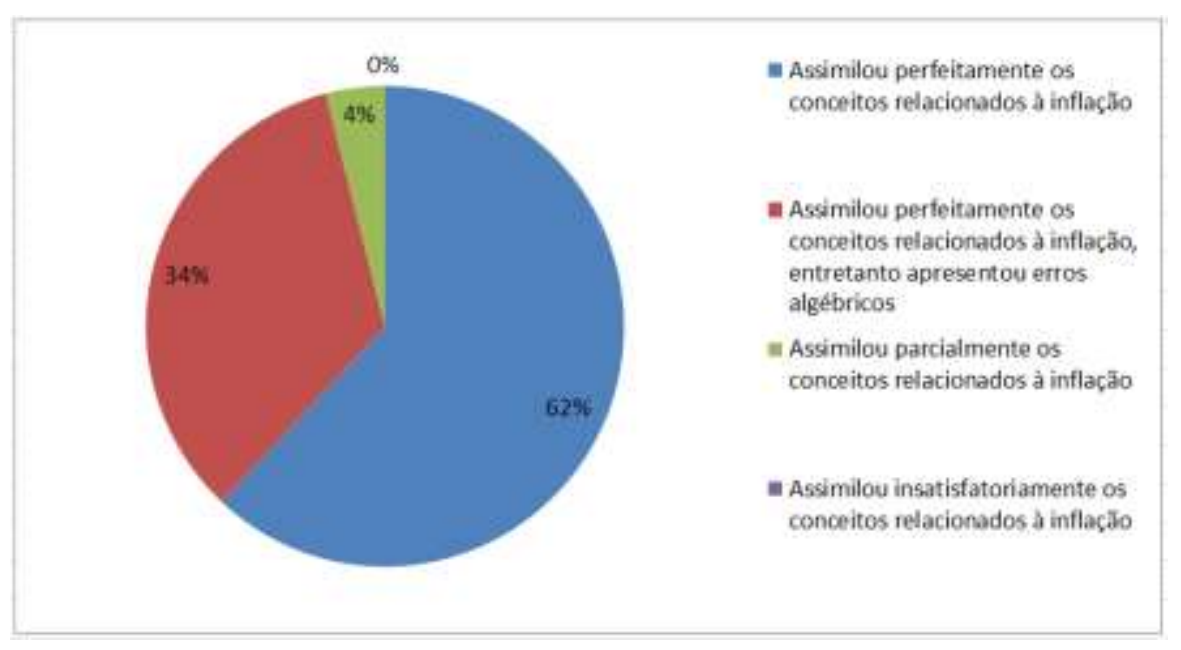

Fonte: dados da pesquisa.

Os resultados apresentados acima, apontam para um progresso significativo no entendimento dos estudantes em relação a todas as etapas da pesquisa e à Educação Financeira como um todo, bem como sua aplicação no cotidiano e o seu impacto no futuro de cada indivíduo. Pôde-se notar um maior nível de maturidade de todos os envolvidos no processo, na sua forma de se portar e de dialogar sobre a temática. 


\section{Considerações finais}

O presente artigo teve por objetivo apresentar um novo prisma sobre a inserção da Educação Financeira nas aulas de matemática através de Teatros, a fim de que as escolas formem cidadãos autocríticos em relação ao uso do dinheiro e à tomada de decisão no que diz respeito às finanças. Foi possível perceber a evolução dos envolvidos, nos quesitos: tomada de decisão, conceituação de termos financeiros e conscientização em relação à gestão financeira.

O Teatro como recurso lúdico foi atividade cerne da experimentação, gerando entendimento e reflexões positivas sobre a Educação Financeira ao longo da pesquisa. Verificou-se através das observações dos pesquisadores e dos registros dos estudantes, que Teatro e Educação Financeira reúnem-se perfeitamente em um só experimento, considerandose a dramatização criativa como um recurso pedagógico eficaz para o desenvolvimento cognitivo, pessoal, emocional e social do estudante. A integração do Teatro e Educação Financeira ofereceu aos pesquisados oportunidades para atuar como protagonista dos seus próprios aprendizados, inseridos em diversos contextos financeiros propriamente encenados por eles.

$\mathrm{Na}$ Atividade 2, os estudantes puderam matematizar a reflexão e os entendimentos gerados nas encenações. Nessa atividade puderam esclarecer dúvidas sobre a Matemática Financeira, gerando reflexões interessantíssimas sobre aplicações dos modelos matemáticos no âmbito familiar. Foi possível observar um excelente desempenho dos estudantes em relação à interpretação de dados e a tomada de decisão, na qual foram desafiados a interpretar situaçõesproblemas reais.

Baseado nas interações, nas participações das atividades propostas e nas resoluções escritas pelos pesquisados, constata-se que o objetivo geral foi atendido, pois o estudante foi capaz de desenvolver o senso de autonomia, tomada de decisão e assimilar os conceitos sobre Educação Financeira através do Teatro. Os estudantes envolvidos na pesquisa puderam compreender a importância do conhecimento sobre juros, impostos, inflação, gereciamento financeiro do lar, investimentos, e criar uma correlação biunívoca entre a Matemática Financeira e Educação Financeira com problemas de finanças reais, de forma lúdica e divertida através do Teatro.

Concluindo, espera-se que esta pesquisa sirva de suporte didático-pedagógico para profissionais do ensino da matemática e os instiguem a inserção do Teatro como um práxis inovador e, a através deste, promover a mudança do cenário atual da Educação Financeira no Brasil. 


\section{Referências}

ABEFIN. Associação Brasileira dos Educadores Financeiros. Disponível em: https://abefin.org.br/. Acesso em 31 mai. 2019.

ALVES, E.C. Teatro: um olhar lúdico à face do desenvolvimento infantil. II Jornada Pedagógica do Lalupe - Olha Multidisciplinar sobre a Ludicidade - II JOPED, 2010, Aquidauana-MS. Anais. Aquidauana-MS: II JOPED, 2010. Disponível em: http://www.joped.uepg.br/2010/anais/oral/20003_1_FINAL.pdf. Acesso em: 24 nov. 2020.

AZEVEDO, M.N.; ABIB, M.L.V. Pesquisa-ação e a elaboração de saberes docentes em ciências. Investigações em Ensino de Ciências, v.18 (1), p.55-75, 2013.

D’AMBROSIO, U. Da realidade a ação: reflexões sobre educação e matemática. $6^{\text {a }}$ ed. São Paulo: Editora Summus, 1986.

DOLCI, L.N. Teatro na Educação: desenvolvendo no aluno a capacidade de integração nos grupos sociais. Revista Electrónica Diálogos Educativos, n.8, p.68-90, 2004.

BRASIL. Decreto Federal 7.397/2010. Câmara dos Deputados. Brasília, DF, 2010. Disponível em: https://www2.camara.leg.br/legin/fed/decret/2010/decreto-7397-22-dezembro-2010609805-normaatualizada-pe.html. Acesso em: 24 nov. 2020.

. Educação financeira nas Escolas: Ensino médio. Bloco 1.1. ed. [S.1.]: Comitê Nacional de Educação Financeira - Ministério da Educação, 2013.v. 1.

. Educação financeira nas Escolas: Ensino médio. Bloco 2.1. 2014a. ed. [S.1.]: Comitê Nacional de Educação Financeira - Ministério da Educação, 2014.v. 1.

. Educação financeira nas Escolas: Ensino médio. Bloco 3.1. 2014b. ed. [S.1.]: Comitê Nacional de Educação Financeira - Ministério da Educação, 2014.v. 1.

. Estratégia nacional de educação financeira - Plano Diretor da ENEF. Brasília, DF, 2017. Disponível em: https://vidaedinheiro.gov.br/. Acesso em 31 mai. 2019

. Base Nacional Comum Curricular (BNCC). Brasília, DF, 2018.

BRUHN, M.; LEAO, L. de S.; LEGOVINI, A.; MARCHETTI, R.; ZIA, B. The impact of high school financial education: experimental evidence from brazil. World Bank Policy Research Working Paper, n.6723, p. 1-30, 2013. Disponível em: http://papers.ssrn.com/sol3/papers.cfm?abstract_id=2367083. Acesso em 06 abr. 2019.

CHIZZOTTI, A. Pesquisa em ciências humanas e sociais. 12 ${ }^{\mathrm{a}}$ ed.São Paulo: Editora Cortez, 2018.

D’AMBROSIO, U. Da realidade a ação: reflexões sobre educação e matemática. $6^{\mathrm{a}}$ ed. São Paulo: Editora Summus, 1986.

D'AQUINO, C. CERBASI, G. E o que é educação financeira? São Paulo, 2016. Disponível em: http://educacaofinanceira.com.br/index.php/escolas/conteudo/513. Acesso em 24 nov. 2020 .

DAVIS, J.H.; BEHM, T. Terminology of drama/theatre with and for children: a redefinition. Children's Theatre Review XXVII, v.(1), p.10-11, 1978.

ENEF. Estratégia Nacional de Educação Financeira. Disponível em: http://www.vidaedinheiro.gov.br/. Acesso em 31 mai. 2019. 
FIGUEIREDO, R.V.de. A formação de professores para a inclusão dos alunos no espaço pedagógico da diversidade. $1^{\mathrm{a}}$ ed. Petrópolis: Vozes, v.1, p.141-145, 2008.

GARCIA, C. J.; CANAL, B.R.; BERNAL, G. A.; MARTÍN G. A.V. El escenario emocional y la dramática de la formación. La Vida Emocional: Las Emociones y la Formación de la Identidad Humana, p.87-126. Ariel: Barcelona - Espanha, 2006.

GEFE-SP. A origem dos impostos. 2019. Disponível em: <https:// www.youtube.com/ watch? $\mathrm{v}=5 \mathrm{P} 4 \mathrm{mzLB} 3 \mathrm{QEw}>$. Acesso em 02 mai. 2019.

GONZAGA, E.T. O teatro como recurso didático para motivar os alunos do $3^{\circ}$ ano do ensino médio na aprendizagem de matemática. 2018. (94f.). Dissertação (Mestrado em Matemática Universidade Estadual do Norte Fluminense Darcy Ribeiro), Campos dos Goytacazes, 2018.

MARTINS, J.P. Seu futuro: Educação financeira e atitudes para conquistar sua independência. $1^{\text {a }}$ ed. Paraná: Editora Fundamento Educacional, 2011.

. Projetos de pesquisa: estratégias de ensino em sala de aula. $2^{\mathrm{a}}$ ed. Campinas: Editora Autores Associados, 2007.

NOGUEIRA, R. N. Pedagogia dos projetos: uma jornada interdisciplinar rumo ao desenvolvimento das múltiplas inteligências. $1^{a}$ ed. São Paulo: Editora Érica, 2003.

OCDE. Organização para a Cooperação e Desenvolvimento Econômico. Paris, França. Disponível em: https://www.oecd.org/brazil/. Acesso em 19 jul. 2019.

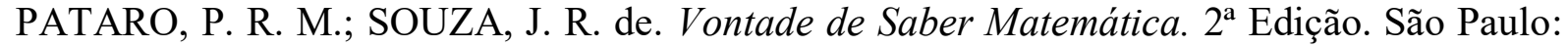
FTD, 2012.

PERUCHI, B.A. Projeto de trabalho: uma aplicação da matemática financeira. 2018. (85 f.). Dissertação (Mestrado em Matemática - Universidade Federal da Fronteira do Sul), Chapecó, 2018.

SAITO, A.T. Uma contribuição ao desenvolvimento da educação em finanças pessoais no Brasil. 2007. (152 f.). Dissertação (Mestrado em Economia - Universidade de São Paulo), São Paulo, 2007.

SAVOIA, J.R.F.; SAITO, A.T.; SANTANA, F.de A. Paradigms of financial education in brazil. Revista de Administração Pública, SCIELO Brasil, v.41, n.6, p.1121-1141, nov./dez. 2007.

SILVA, A.M. da; POWELL, A.B. Um programa de educação financeira para a matemática escolar da educação básica. XI Encontro Nacional de Educação Matemática, 2013, Curitiba. Anais. Curitiba: XI ENEM, 2013.

SOUZA, D.P.D. A importância da educação financeira infantil. 2012. (76 f.) Trabalho de Conclusão de Curso (Bacharel em Ciências Contábeis - Faculdade de Ciências Sociais Aplicadas do Centro Universitário Newton Paiva), Belo Horizonte, 2012. Disponível em: http://www.educacaofinanceira.com.br/tcc/importancia-da-educacao-financeira-infantil.pdf. Acesso em 24 nov. 2020.

VIGOTSKI, L.S. Imaginação e criação na infância. São Paulo: Editora Ática, 2009. . A formação social da mente. São Paulo: Editora Martins Fontes, 1989. 